\title{
Propofol sequestration within the \\ extracorporeal circuit
}

Markku Hynynen MD, Esa Hammarén MD, Per H. Rosenberg MD
Various drugs administered during cardiac anaesthesia are sequestered in the extracorporeal circuit in vitro, but it is uncertain whether this sequestration phenomenon affects plasma drug concentration in vivo. The present study was undertaken to evaluate (1) in vitro sequestration of propofol in the extracorporeal circuit and (2) whether the change in plasma propofol concentration induced by initiation of cardiopulmonary bypass in vivo can be explained by haemodilution. For the in vitro evaluation, three separate experiments with a closed circuit (membrane oxygenator, reservoir, and tubings) were performed. The $\mathrm{pH}$ and $\mathrm{PCO}_{2}$ of the circulating solution (a mixture of Ringer's acetate and whole blood) were maintained within the normal physiological range, and the temperature of the solution was $28^{\circ} \mathrm{C}$. The solution was circulated at a flow of $4 \mathrm{~L} \cdot \mathrm{min}^{-1}$ and propofol was added to the solution to achieve a concentration of $2 \mu \mathrm{g} \cdot \mathrm{ml}^{-1}$. Serial samples were taken from the circulating solution for measurement of propofol concentration by high performance liquid chromatography. In the in vivo part of the study, 14 patients received a continuous infusion of propofol, and samples for the determination of plasma propofol concentration and blood haematocrit were taken before and five and ten minutes afier initiation of cardiopulmonary bypass. In vitro, at 5 and $120 \mathrm{~min}$ after addition of propofol into the circulating solution, approximately $65 \%$ and $25 \%$, respectively, of the predicted propofol level was measurable in the solution. In vivo, five minutes after initiation of the cardiopulmonary bypass plasma propofol concentration decreased $(P<0.001)$ more (from $2.8 \pm 0.7$ (mean $\pm S D$ ) to $1.5 \pm 0.5 \mu \mathrm{g} \cdot \mathrm{ml}^{-1}$,

\section{Key words}

ANAESTHESIA: candiac;

ANAESTHETICS, INTRAVENOUS: propofol;

PHARMACOKINETICS, SURGERY: cardiac, cardiopulmonary bypass, extracorporeal circulation.

From the Department of Anaesthesia, Helsinki University Central Hospital, Helsinki, Finland.

Address correspondence to: Dr. Markku Hynynen, Department of Anaesthesia, Helsinki University Central Hospital, Haartmaninkatu 4, FIN-00290 Helsinki, Finland.

This study was supported in part by a research grant from the Paulo Foundation, Finland. Zeneca Pharma, Finland, has supplied financial support for the in vitro experiments.

Accepted for publication 28th March, 1994. a $45 \pm 12 \%$ decrease) than would have been predicted on the basis of acute haemodilution (a decrease in haematocrit from $0.39 \pm 0.04$ to $0.28 \pm 0.03$ is a $29 \pm 4 \%$ decrease). Ten minutes after initiation of cardiopulmonary bypass, plasma propofol concentration was $1.6 \pm 0.5 \mu \mathrm{g} \cdot \mathrm{ml}^{-1}$ (a $37 \pm 27 \%$ decrease from the pre-bypass level) and haematocrit was $0.27 \pm 0.04$ (a $30 \pm 6 \%$ decrease): the decrease in plasma propofol concentration was not different from the decrease observed in the haematocrit. In conclusion, propofol is markedly sequestered within the extracorporeal circuit in vitro. This sequestration may, to some extent, affect plasma propofol concentration in vivo.

Cette étude vise à déterminer 1) limportance de la séquestration in vitro du propofol dans le circuit de circulation extracorporelle (CEC) et 2) si l'hémodilution seule peut expliquer in vivo les changements de concentration plasmatique qui surviennent après linitiation de la CEC. Pour l'étude in vitro, trois expériences en circuit fermé séparées (oxygénateur à membrane, réservoir et tubulures) sont effectuées. Le pH et la $\mathrm{PCO}_{2}$ de la solution circulée sont maintenus dans les limites de la normale physiologique avec une température de $28^{\circ} \mathrm{C}$. La solution circule avec un débit de $4 \mathrm{~L} \cdot \mathrm{min}^{-1}$ et du propofol est ajouté à la solution pour obtenir une concentration de $2 \mu \mathrm{g} \cdot \mathrm{ml}^{-1}$. Des échantillons en série sont prélevés pour la mesure de la concentration du propofol par chromatographie en phase liquide à haute performance. Pour l'étude in vivo, 14 patients reçoivent du propofol en perfusion continue et des échantillons sont prélevés pour déterminer la concentration plasmatique de propofol et l'hématocrite à cinq et dix minutes après le début de la CEC. In vitro, à 5 et $120 \mathrm{~min}$ après l'ajout du propofol dans la solution circulée, environ $65 \%$ et $25 \%$ respectivement du niveau de propofol prédit sont mesurables dans la solution. In vivo, cinq minutes après línitiation de la CEC, la concentration plasmatique de propofol diminue $(P<0,001) \grave{a}$ un degré plus considérable (de 2,8 $\pm 0,7$ moyenne $\pm S D$ à 1,5 $\pm 0.5 \mu \mathrm{g} \cdot \mathrm{ml}^{-1}$, une baisse de $45 \pm 12 \%$ ) qu'on pouvait le prédire sur la base de lhémodilution aiguë (une baisse de lhématocrite de $0,39 \pm 0,04$ à $0,28 \pm 0,03$, soit une baisse de $29 \pm 4 \%$ ). Dix minutes après linitiation de la CEC, la concentration plasmatique de propofol est de $1,6 \pm 0,5$ $\mu \mathrm{g} \cdot \mathrm{ml}^{-1}$ (une baisse de $37 \pm 27 \%$ du niveau pré-CEC) et lhématocrite se situe à 0,27 $\pm 0,04$ (une baisse de $30 \pm 6 \%$ ); la baisse de la concentration plasmatique de propofol n'est pas 
différente de la baisse de l'hématocrite. En conclusion, la séquestration in vitro du propofol dans le circuit de CEC est considérable. Cette séquestration peut affecter jusqu'à un certain point la concentration de propofol in vivo.

The use of propofol in cardiac anaesthesia has been previously described. ${ }^{1-5}$ In combination with opioids a mean blood propofol concentration of $2.4 \mu \mathrm{g} \cdot \mathrm{ml}^{-1}$ was associated with the prevention of untoward haemodynamic responses to noxious stimuli during the pre-bypass period of cardiac surgery. ${ }^{1}$ Likewise, with opioids, mean blood propofol concentrations of "greater than $1 \mu \mathrm{g} \cdot \mathrm{ml}^{-1 \text { "2 }}$ or $2.4 \mu \mathrm{g} \cdot \mathrm{ml}^{-1}$, were associated with sufficient depth of anaesthesia to prevent recall and awareness during the cardiac surgical procedure. Although a stable plasma anaesthetic drug level can be maintained before cardiopulmonary bypass (CPB), the initiation of the CPB phase of cardiac surgery induces a decrease in plasma concentration of many drugs. ${ }^{6,7}$ This phenomenon has also been reported with propofol. ${ }^{1}$ The decrease in blood propofol concentration during CPB was attributed to haemodilution, ${ }^{1}$ but an additional factor might be the sequestration of propofol to the components of the CPB circuit. The present investigation was performed to evaluate whether or not propofol is sequestered to the CPB circuit under in vitro conditions. Also, in 14 patients undergoing coronary artery bypass surgery, we evaluated the changes in plasma propofol concentration following initiation of extracorporeal circulation.

\section{Methods}

\section{In vitro experiments}

Three separate extracorporeal circuits comprising a hollow fibre membrane oxygenator and a reservoir (D 703 Compactflo ${ }^{\circledR}$ System, Dideco, Mirandola, Italy) and silicone and polyvinylchloride tubings were used. The circuit was primed with a mixture of two units of just outdated whole blood and Ringer's acetate solution. The total volume of the priming solution was $2000 \mathrm{ml}$. Heparin $5000 \mathrm{IU}$ was added to the solution. The solution was circulated at a flow rate of $4 \mathrm{~L} \cdot \mathrm{min}^{-1}$, and oxygen $2 \mathrm{~L} \cdot \mathrm{min}^{-1}$ was added into the circuit. Carbon dioxide was added to maintain $\mathrm{PCO}_{2}$ between 35-45 $\mathrm{mmHg}(4.7-6.0 \mathrm{kPa})$ and the $\mathrm{pH}$ was adjusted to 7.35-7.45 with trometamol (Addex ${ }^{\oplus}$-THAM, Kabi Vitrum AB, Stockholm, Sweden), as assessed according to the $\alpha$-stat principle, i.e., the values were measured at $37^{\circ} \mathrm{C}$ and they were not corrected to the actual temperature. The temperature of the circulating solution was maintained at $28^{\circ} \mathrm{C}$ with a heat exchanger.

Propofol was infused as a bolus dose through a stop- cock as rapidly as possible into the venous site of the circuit to achieve a calculated concentration of $2 \mu \mathrm{g} \cdot \mathrm{ml}^{-1}$ in the solution. The concentration of the propofol bolus was $10 \mathrm{mg} \cdot \mathrm{ml}^{-1}$ and $0.4 \mathrm{ml}$ was infused. Samples for the determination of propofol concentration were drawn from the arterial site of the circuit through the arterialvenous sampling stopcock before, and at $5,10,20,40$, 60 and $120 \mathrm{~min}$ after the addition of the drug. The samples were taken into prechilled heparinized tubes and centrifuged at $+4^{\circ} \mathrm{C}$ with $3000 \mathrm{rpm}$ for ten minutes, and the plasma samples were stored at $-70^{\circ} \mathrm{C}$ until assayed. Propofol concentration was determined by an HPLC method. ${ }^{8}$ The lower limit of detection was $5 \mathrm{ng} \cdot \mathrm{ml}^{-1}$, and the intra-assay coefficient of variation was about $5 \%$.

\section{In vivo study}

Fourteen patients undergoing elective coronary artery bypass graft surgery were studied. The protocol was accepted by the Ethical Committee, and each patient gave his/her informed consent. The patients received their regular cardiovascular medications on the morning of surgery, and they were premedicated with scopolamine $5 \mu \mathrm{g} \cdot \mathrm{kg}^{-1}$ and morphine $160 \mu \mathrm{g} \cdot \mathrm{kg}^{-1} \mathrm{im}$ one hour before their arrival in the operating room. Anaesthesia was induced with fentanyl $30 \mu \mathrm{g} \cdot \mathrm{kg}^{-1}$ and pancuronium $0.1 \mathrm{mg} \cdot \mathrm{kg}^{-1}$. Simultaneously, a maintenance infusion of fentanyl $0.15 \mu \mathrm{g} \cdot \mathrm{kg}^{-1} \cdot \mathrm{min}^{-1}$ was started. At the start of $\mathrm{CPB}$, the rate of the fentanyl infusion was reduced to $0.075 \mu \mathrm{g} \cdot \mathrm{kg}^{-1} \cdot \mathrm{min}^{-1}$ to be continued until the end of the study. Anaesthesia was supplemented with isoflurane $(n=7)$ or enflurane $(n=7)$, if systolic arterial pressure increased to $>120 \mathrm{mmHg}(16 \mathrm{kPa})$. Before the start of surgery, a continuous infusion of propofol was started into the right ventricular port of the pulmonary artery catheter at a rate of $10 \mathrm{mg} \cdot \mathrm{kg}^{-1} \cdot \mathrm{hr}^{-1}$ according to Russell et al. ${ }^{1}$ After $20 \mathrm{~min}$, the rate of the infusion was reduced to $3 \mathrm{mg} \cdot \mathrm{kg}^{-1} \cdot \mathrm{hr}^{-1}$ to be maintained unchanged until the end of the study. After induction of anaesthesia, the trachea was intubated and the lungs were mechanically ventilated with a mixture of oxygen and air $\left(\mathrm{FIO}_{2} \mathbf{0 . 5 0}\right)$. Normocarbia was maintained as assessed by continuously monitoring the end-tidal $\mathrm{CO}_{2}$ concentration and by intermittently measuring the arterial $\mathrm{PCO}_{2}$. During $\mathrm{CPB}$, the lungs were vented to ambient air. During CPB, the pulmonary artery catheter was withdrawn to a position, where a pulmonary capillary wedge pressure curve could not be obtained in onder to avoid inadvertent wedging during CPB.

Cardiopulmonary bypass was conducted with nonpulsatile flow (Stöckert, Munich, Germany) and a similar circuit as described above in the "in vitro" section. The circuit was primed with $2000 \mathrm{ml}$ Ringer's acetate solution 
TABLE I Study conditions in an in vitro extracorporeal circulation of 120 -min duration (mean \pm SD)

\begin{tabular}{lccccc}
\hline \multirow{5}{*}{ Variable } & \multicolumn{5}{l}{ Time (min) from start of the experiment } \\
\cline { 2 - 6 } & 0 & 10 & 30 & 60 & 120 \\
\hline $\mathrm{pH}$ & $7.38 \pm 0.04$ & $7.37 \pm 0.02$ & $7.38 \pm 0.02$ & $7.39 \pm 0.02$ & $7.37 \pm 0.02$ \\
$\mathrm{PCO}_{2}(\mathrm{kPa})$ & $5.0 \pm 0.2$ & $5.6 \pm 0.6$ & $5.3 \pm 0.4$ & $5.1 \pm 0.4$ & $5.5 \pm 0.5$ \\
$\mathrm{PO}_{2}(\mathrm{kPa})$ & $94 \pm 2$ & $100 \pm 2$ & $93 \pm 4$ & $91 \pm 2$ & $87 \pm 17$ \\
$\mathrm{Haematocrit}$ & $0.15 \pm 0.02$ & $\mathrm{NA}$ & $\mathrm{NA}$ & $\mathrm{NA}$ & $0.11 \pm 0.01$ \\
\hline
\end{tabular}

$\mathrm{NA}=$ not assessed.

and heparin $5000 \mathrm{IU}$. The pump flow was maintained at $2.4 \mathrm{~L} \cdot \mathrm{min}^{-1} \cdot \mathrm{m}^{-2}$ until the end of the study (until the last blood sample). Systemic anticoagulation was achieved with an initial dose of $300 \mathrm{IU} \cdot \mathrm{kg}^{-1}$ heparin and with subsequent additional doses of heparin to maintain the ACT-value $>480 \mathrm{sec}$. The patients were cooled to a nasopharyngeal temperature of $28^{\circ} \mathrm{C}$.

Blood samples for the determination of plasma propofol concentration and haematocrit were taken into prechilled heparinized tubes from a radial artery cannula before CPB and from the oxygenator (arterialized blood) during CPB. The samples were taken (1) five minutes after the administration of heparin (at least $\mathbf{4 0} \mathrm{min}$ after the start of the loading infusion of propofol and at least $20 \mathrm{~min}$ after the start of the maintenance infusion), (2) immediately before the start of CPB (during the cannulation of the caval veins/right atrium, $16 \pm 3 \mathrm{~min}$ (range 10-22) after sample 1), (3) five minutes after the start of CPB and (4) ten minutes after the start of CPB. The samples were further handled as the "in vitro" samples described above.

\section{Statistical analysis}

In the in vivo study, analysis of variance for repeated measures was used to detect any change over the course of the study in the variables. For subsequent multiple comparisons, $t$ test for paired data was used adjusted by the Bonferroni correction. A $P$-value $<0.05$ was considered significant. The results are given as the mean \pm SD.

\section{Results}

\section{In vitro experiments}

The study conditions were stable during the 120-min circulation period (Table I). Propofol concentrations were lower than predicted, i.e., $2 \mu \mathrm{g} \cdot \mathrm{ml}^{-1}$, even in the fiveminute sample (Figure 1). Propofol concentrations continued to decrease during the experiment, and at the end (at $120 \mathrm{~min}$ ) only approximately $25 \%$ of the initial predicted concentration could be measured in the circulating extracorporeal solution.

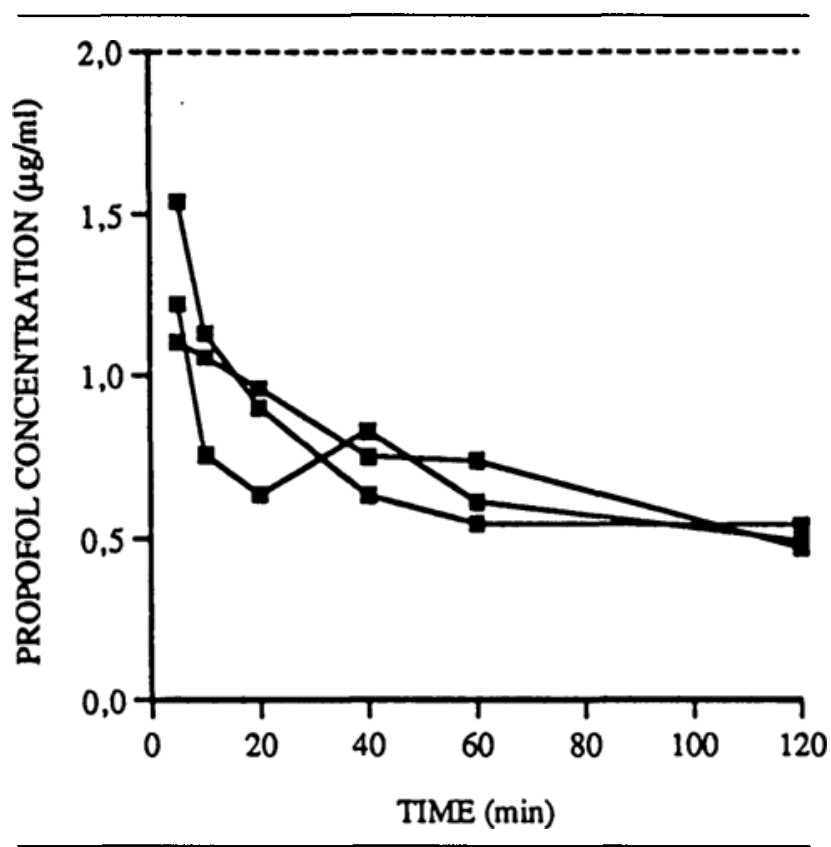

FIGURE Propofol concentration of three experiments in isolated cardiopulmonary bypass systems during a 120 -min circulation. The predicted propofol concentration (as indicated by a dashed line) was 2 $\mu \mathrm{g} \cdot \mathrm{ml}^{-1}$.

TABLE II Preoperative patient characteristics (number of patients or mean $\pm S D)$

\begin{tabular}{ll}
\hline Sex $(\mathrm{M} / \mathrm{F})$ & $12 / 2$ \\
Age $(\mathrm{yr})$ & $57 \pm 8$ \\
Weight $(\mathrm{kg})$ & $89 \pm 11$ \\
Height $(\mathrm{cm})$ & $172 \pm 6$ \\
Ejection fraction of left ventricle & $0.52 \pm 0.15$ \\
Regular drug therapy & \\
- Beta-adrenergic blocker & 14 \\
- Calcium-channel blocker & 9 \\
- Long-acting nitrate & 14 \\
\hline
\end{tabular}

$\mathrm{M} / \mathrm{F}=$ male $/$ female

In vivo study

The preoperative patient data are given in Table II. During the pre-bypass period, haematocrit and propofol concentrations remained stable. During CPB, i.e., five and 
TABLE III Haematocrit and plasma propofol concentration $\left(\mu \mathrm{g} \cdot \mathrm{ml}^{-1}\right)$ in 14 patients receiving a continuous infusion of propofol and undergoing cardiopulmonary bypass (individual values and mean \pm SD)

\begin{tabular}{|c|c|c|c|c|c|c|c|c|c|c|c|c|}
\hline \multirow[b]{3}{*}{ Patient \# } & \multirow{2}{*}{\multicolumn{2}{|c|}{ After heparin }} & \multirow{2}{*}{\multicolumn{2}{|c|}{ Before $C P B$}} & \multicolumn{4}{|c|}{ During $C P B(5 \mathrm{~min})$} & \multicolumn{4}{|c|}{ During $C P B(10 \mathrm{~min})$} \\
\hline & & & & & \multirow[b]{2}{*}{$\mathrm{Hct}$} & \multirow{2}{*}{$\begin{array}{l}\text { Pencent } \\
\text { decrease }\end{array}$} & \multirow[b]{2}{*}{ Propofol } & \multirow{2}{*}{$\begin{array}{l}\text { Percent } \\
\text { decrease }\end{array}$} & \multirow[b]{2}{*}{$\mathrm{Hct}$} & \multirow{2}{*}{$\begin{array}{l}\text { Percent } \\
\text { decrease }\end{array}$} & \multirow[b]{2}{*}{ Propofol } & \multirow{2}{*}{$\begin{array}{l}\text { Percent } \\
\text { decrease }\end{array}$} \\
\hline & $H c t$ & Propofol & $H c t$ & Propofol & & & & & & & & \\
\hline 1 & 0.41 & 3.7 & 0.40 & 3.0 & 0.31 & 23 & $1.0^{\circ}$ & 67 & 0.29 & 28 & 0.8 & 73 \\
\hline 2 & 0.45 & 4.3 & 0.44 & 4.0 & 0.30 & 32 & 2.7 & 33 & 0.31 & 30 & 2.7 & 33 \\
\hline 3 & 0.35 & 4.0 & 0.35 & 3.9 & 0.25 & 29 & 2.1 & 46 & 0.26 & 26 & 1.8 & 54 \\
\hline 4 & 0.40 & 2.8 & 0.39 & 2.3 & 0.30 & 23 & 1.3 & 43 & 0.29 & 26 & 1.3 & 43 \\
\hline 5 & 0.36 & 2.6 & 0.35 & 3.0 & 0.23 & 34 & 1.4 & 53 & 0.22 & 37 & 1.6 & 47 \\
\hline 6 & 0.44 & 2.6 & 0.43 & 2.5 & 0.33 & 23 & 1.1 & 56 & 0.34 & 21 & 1.5 & 40 \\
\hline 7 & 0.30 & 1.8 & 0.32 & 1.5 & 0.23 & 28 & 1.1 & 27 & 0.22 & 31 & 1.9 & -27 \\
\hline 8 & 0.43 & 2.3 & 0.43 & 2.7 & 0.29 & 33 & 1.4 & 48 & 0.28 & 35 & 1.3 & 52 \\
\hline 9 & 0.37 & 3.0 & 0.38 & 2.2 & 0.27 & 29 & 1.0 & 55 & 0.27 & 29 & 2.4 & -9 \\
\hline 10 & 0.42 & 4.0 & 0.41 & 3.1 & 0.27 & 34 & 1.3 & 58 & 0.26 & 37 & 1.3 & 58 \\
\hline 11 & 0.39 & 1.8 & 0.38 & 2.5 & 0.29 & 24 & 1.8 & 28 & 0.28 & 26 & 2.1 & 16 \\
\hline 12 & 0.39 & 2.8 & 0.38 & 3.0 & 0.28 & 26 & 1.9 & 37 & 0.29 & 24 & 1.8 & 40 \\
\hline 13 & 0.45 & 2.4 & 0.45 & 2.4 & 0.32 & 29 & 1.3 & 46 & 0.31 & 31 & 1.0 & 58 \\
\hline 14 & 0.37 & 2.4 & 0.35 & 2.6 & 0.23 & 34 & 1.6 & 38 & 0.21 & 40 & 1.4 & 46 \\
\hline Mean & 0.40 & 2.9 & 0.39 & 2.8 & $0.28 *$ & 29 & $1.5^{*}$ & $45 \dagger$ & $0.27^{*}$ & 30 & $1.6^{*}$ & 37 \\
\hline $\mathrm{SD}$ & 0.04 & 0.8 & 0.04 & 0.7 & 0.03 & 4 & 0.5 & 12 & 0.04 & 6 & 0.5 & 27 \\
\hline
\end{tabular}

$\mathrm{CPB}=$ cardiopulmonary bypass. $\mathrm{Hct}=$ haematocrit.

$* P<0.001$ vs the "Before CPB"-sample.

$\dagger P<0.001$ vs the corresponding change in haematocrit.

$\ddagger$ Percent decrease indicates the decrease from the "before CPB"-value.

ten minutes after the start of CPB, haematocrit and propofol concentrations were lower than the values before CPB (Table III).

Rectal temperature decreased $(P<0.001)$ from the pre-bypass value of $36.1 \pm 0.8^{\circ} \mathrm{C}$ to $35.3 \pm 1.1^{\circ} \mathrm{C}$ within five minutes from the start of $\mathrm{CPB}$ and to $34.6 \pm 1.4^{\circ} \mathrm{C}$ within ten minutes. There was no correlation $(R=0.169$, $P=\mathrm{NS}$ ) between the change in plasma propofol concentration from the pre-bypass value until the ten-minute value and the corresponding change in rectal temperature.

In all patients, propofol concentrations were lower after five minutes from the start of CPB than before CPB. Still, after ten minutes from the start of CPB, propofol concentrations were lower than the pre-bypass concentrations in all except two patients (\#7 and \#9) (Table III). Five minutes after the start of $\mathrm{CPB}$, the decrease in propofol concentration from the pre-bypass level was greater $(P<0.001)$ than the corresponding change in haematocrit. Ten minutes after the start of $\mathrm{CPB}$, the decreases from the pre-bypass level were not different in propofol concentration and haematocrit.

\section{Discussion}

The present experiment demonstrates that propofol is markedly sequestered to the extracorporeal circuit in vitro. Thus, propofol is another among an increasing number of drugs now known to become sequestered to the CPB circuit. Others, relevant for anaesthesia, are e.g.,

nitroglycerin, ${ }^{9}$ fentanyl 10 and thiopentone. ${ }^{11}$ The clinical importance of this phenomenon is uncertain, but the sequestration might, at least in part, contribute to the decrease in plasma anaesthetic drug concentration of the patient observed during CPB.,10 Such a sequestration might also increase the consumption of an anaesthetic drug during CPB. Rosen et al. ${ }^{12}$ have suggested that the capacity of a CPB oxygenator to absorb an anaesthetic drug (fentanyl in their case) might be considerable.

Our observation of the sequestration of propofol to the CPB circuit seems to be in accordance with the preliminary observation of Tarr and Kent. ${ }^{13}$ They found that the propofol concentrations in the extracorporeal circuit decreased to $50 \%$ or less of the predicted value within 10 to $15 \mathrm{~min}$. There are some differences in the experimental conditions between the study of Tarr and Kent and that of ours: (1) a temperature of $37^{\circ} \mathrm{C}$ in the former vs $28^{\circ} \mathrm{C}$ in the latter, (2) no comment of the $\mathrm{pH}$ and $\mathrm{PCO}_{2}$ adjustment by Tarr and Kent vs the normal physiological range of $\mathrm{pH} 7.35-7.45$ and of $\mathrm{PCO}_{2} 35-45$ $\mathrm{mmHg}$ in the present study and (3) no exact value in the predicted propofol concentration in the study of Tarr and Kent, i.e., the concentration was expected to be somewhere between 2-4 $\mu \mathrm{g} \cdot \mathrm{ml}^{-1}$, vs. that of exactly 2 $\mu \mathrm{g} \cdot \mathrm{ml}^{-1}$ in our experiment. In addition, a Cobe CML(\$) membrane oxygenator was used by Tarr and Kent vs a Compactflo ${ }^{\oplus}$ membrane oxygenator by us, and an arterial line filter in the cited study vs no filter in the present 
experiment. In spite of these differences, both studies describe the phenomenon of propofol sequestration to the CPB circuit.

We also measured plasma propofol concentrations in a clinical setting in patients undergoing CPB. The mean decrease in plasma propofol concentration with initiation of CPB was greater than would have been expected on the basis of haemodilution only. This may indicate that the sequestration of propofol to the CPB circuit can affect the plasma concentration of propofol to a clinically relevant degree. However, the anaesthetic drug concentrations during CPB are affected by many other factors, 14,15 such as the change in plasma protein binding of the drug and the temperature, among others. Russell et al. ${ }^{\prime}$ reported that, as assessed in three patients, the unbound fraction of propofol increased by a factor of 1.5 to 3 during $\mathrm{CPB}$ compared with the pre-bypass values. This is well in accordance with the observations of others that plasma protein binding of drugs, e.g., thiopentone ${ }^{7}$ and alfentanil, ${ }^{16}$ is decreased during CPB. Unfortunately, Russell et al. ${ }^{1}$ did not report the unbound concentrations of plasma propofol in their three subjects. Nevertheless, the possible change in the unbound fraction of propofol might be another contributory factor in the change observed in plasma total propofol concentration in our patients at the onset of CPB. The issue of unbound concentration of plasma propofol during CPB requires further evaluation.

Although the mean plasma propofol concentration was decreased during CPB from the pre-bypass level, there existed considerable inter-individual variability. In two patients, ten minutes after the start of CPB, plasma propofol concentrations were even higher than before CPB. This might be an expression of a redistribution phenomenon of propofol occasionally seen as relatively high secondary peaks in propofol blood concentration. ${ }^{8}$ In addition, especially in patients undergoing $\mathrm{CPB}$ and receiving drugs through a central route, there may exist secondary concentration peaks with delayed appearance of a drug into the arterial outflow cannula. ${ }^{17}$ In our patients, who received propofol into the right ventricular port of the pulmonary artery catheter, surgical manipulation of the heart might also have been responsible for the unexpected variation in propofol concentrations in samples drawn from the outflow (arterial) cannula. The metabolism of propofol, being a cytochrome P450dependent process, is likely to be influenced by temperature. Therefore, we evaluated the possibility that the change in the temperature from the pre-bypass period until that during CPB might explain the variability in plasma propofol concentration. However, no relationship was observed between the change in the core temperature and that in plasma propofol concentration. This seems to indicate that temperature did not contribute to the changes observed in propofol concentration in our patients.

The fact that we measured the propofol concentration in the cell-free solution, while many previous investigators $1,2,13$ have measured propofol concentration in whole blood, should not influence the results. As studied in vitro with human blood, propofol is uniformly distributed between whole blood and plasma. ${ }^{18}$ Although we did not measure the distribution in our system, it is quite probable that the propofol concentration in the cell-free fraction of the centrifugate was equal to the concentration in the circulating solution.

In conclusion, we have shown that propofol is sequestered to the CPB circuit under in vitro conditions which simulate clinical circumstances. However, the contribution of this phenomenon to the anaesthetic care of the cardiac surgical patient remains to be determined. The nonuniform changes in plasma propofol concentration in our patients suggest a drug-specific and possibly a procedure-specific influence on circulating propofol concentrations.

\section{Acknowledgements}

We gratefully acknowledge the technical assistance by Dr. Olli Muikku and the propofol assays performed by Ms. Maria Rosenberg.

\section{References}

1 Russell GN, Wright EL, Fox MA, Douglas EJ, Cockshott ID. Propofol-fentanyl anaesthesia for coronary artery surgery and cardiopulmonary bypass. Anaesthesia 1989; 44: 205-8.

2 Massey NJA, Sherry KM, Oldroyd S, Peacock JE. Pharmacokinetics of an infusion of propofol during cardiac surgery. Br J Anaesth 1990; 65: 475-9.

3 Hall RI, Murphy JT, Moffitt EA, Landymore R, Pollak $P T$, Poole $L$. A comparison of the myocardial metabolic and haemodynamic changes produced by propofolsufentanil and enflurane-sufentanil anaesthesia for patients having coronary artery bypass graft surgery. Can $\mathbf{J}$ Anaesth 1991; 38: 996-1004.

4 Underwood SM, Davies SW, Feneck RO, Walesby RK. Anaesthesia for myocardial revascularisation. A comparison of fentanyl/propofol with fentanyl/enflurane. Anaesthesia 1992; 47: 939-45.

5 Searle NR, Sahab P. Propofol in patients with cardiac disease. Can J Anaesth 1993; 40: 730-47.

6 Hynynen M, Takkunen $O$, Salmenperö $M$, Haataja $H$, Heinonen $J$. Continuous infusion of fentanyl or alfentanil for coronary artery surgery. Plasma opiate concentrations, haemodynamics and postoperative course. $\mathrm{Br} \mathrm{J}$ Anaesth 1986; 58: 1252-9. 
7 Morgan DJ, Crankshaw DP, Prideaux PR, Chan HNJ, Boyd $M D$. Thiopentone levels during cardiopulmonary bypass. Changes in plasma protein binding during continuous infusion. Anaesthesia 1986; 41: 4-10.

8 Cockshott ID, Briggs LP, Douglas EJ, White $M$.

Pharmacokinetics of propofol in female patients. Studies using single bolus injections. $\mathrm{Br} \mathrm{J}$ Anaesth 1987; 59: 1103-10.

9 Dasta JF, Jacobi J, Wu LS, et al. Loss of nitroglycerin to cardiopulmonary bypass apparatus. Crit Care Med 1983; 11: $50-2$.

10 Hynynen $M$. Binding of fentanyl and alfentanil to the extracorporeal circuit. Acta Anaesthesiol Scand 1987; 31: 706-10.

11 Hynynen M, Olkkola KT, Näveri E, Palojoki $R$, Neuvonen PJ, Heinonen J. Thiopentone pharmacokinetics during cardiopulmonary bypass with a nonpulsatile or pulsatile flow. Acta Anaesthesiol Scand 1989; 33: 554-60.

12 Rosen $D A$, Rosen $K R$, Silvasi $D L$. In vitro variability in fentanyl absorption by different membrane oxygenators. $\mathbf{J}$ Cardiothorac Anesth 1990; 4: 332-5.

13 Tarr TJ, Kent AP. Sequestration of propofol in an extracorporeal circuit (Abstract). J Cardiothorac Anesth 1989; 3 (Suppl 1): 75.

14 Buylaert WA, Herregods LL, Mortier EP, Bogaert MG. Cardiopulmonary bypass and the pharmacokinetics of drugs. An update. Clin Pharmacokinet 1989; 17: 10-26.

15 Hall $R$. The pharmacokinetic behaviour of opioids administered during cardiac surgery. Can J Anaesth 1991; 38 : 747-56.

16 Hynynen M, Hynninen M, Soini H, Neuvonen PJ, Heinonen J. Plasma concentration and protein binding of alfentanil during high-dose infusion for cardiac surgery. $\mathrm{Br}$ $J$ Anaesth (in press).

17 Kamath BSK, Thomson DM, Johnston B. Administration of drugs during cardiopulmonary bypass. An analysis of the fate of a bolus injected through different routes using radio-active technetium. Anaesthesia 1980; 35: 908-13.

18 Cockshou ID, Douglas EJ, Plummer GF, Simons PJ. The pharmacokinetics of propofol in laboratory animals. Xenobiotica 1992; 22: 369-75. 